\title{
Pengarusutamaan Gender Dan Inklusi Sosial Dalam Pembangunan Desa
}

\author{
Retno Kusumawiranti \\ Program Studi Administrasi Publik Universitas Widya Mataram \\ retno zan@yahoo.co.id
}

\begin{abstract}
Abstraksi
Kemiskinan menjadi salah satu permasalahan utama dalam pembangunan nasional. Pasca Millenium Development Goals (MDG's) yang dilanjutkan dengan Sustainable. Development Goals (SGD's) Pemerintah Indonesia terus berupaya memberikan perhatian terhadap pembangunan yang berkeadilan dan memihak kepada kelompok terpinggirkan. Oleh karena pembangunan saat ini masih banyak menerapkan model pembangunan eksklusif., maka pembangunan yang inklusif saat ini menjadi agenda utama dan pertimbangan penting dalam pembangunan nasional. Pemerintah Desa mempunyai tugas dalam penyelenggaraan Pemerintahan desa, pelaksanaan pembangunan Desa, pembinaaan kemasyarakatan Desa, dan pemberdayaan masyarakat Desa. Pembangunan masyarakat berarti menaruh kepercayaan pada kemampuan yang ada dalam diri masyarakat itu sendiri. Kepercayaan ini dinyatakan dalam bentuk kesempatan yang sama, kebebasan memilih dan kekuasaan untuk memilih (empowerment). Pembahasan mengenai gender dan inklusivitas dalam kaitannya dengan pembangunan, harus terlebih dahulu memastikan keberadaan komponen yang ada dalam masyarakat dengan melakukan identifikasi berbagai kelompok kepentingan yang ada dalam masyarakat.
\end{abstract}

Kata kunci: Pengarusutamaan gender, inklusi sosial, pembangunan desa

\begin{abstract}
Poverty is one of the main problems in national development. Post Millennium Development Goals (MDGs) which were continued with Sustainable. Development Goals (SGD's) The Indonesian government continues to strive to pay attention to development that is just and pro to marginalized groups. Due to the fact that current development still applies a lot of exclusive development models, inclusive development is currently the main agenda and an important consideration in national development. The Village Government has the task of carrying out village governance, implementing Village development, fostering Village communities, and empowering Village communities. Community development means putting trust in the abilities that exist within the community itself. This belief is expressed in the form of equal opportunity, freedom of choice and power to choose (empowerment). Discussions on gender and inclusiveness in relation to development, must first ensure the existence of components that exist in society by identifying the various interest groups that exist in society.
\end{abstract}

Keywords: Gender mainstreaming, social inclusion, village development

\section{Pendahuluan}

Berlakunya Undang-Undang Nomor 6 Tahun 2014 tentang Desa meletakkan posisi desa sebagai kesatuan masyarakat hukum adat sesuai hak asal usul desa, sehingga otonomi desa diakui dan dihormati dalam sistem pemerintahan Negara Kesatuan Republik Indonesia. Di sisi lain, dalam posisi Desa sebagai subsistem dari sistem penyelenggaraan secara nasional dan jajaran terdepan dalam penyelenggaraan pemerintahan secara nasional, maka desa juga diberi kewenangan untuk menyelenggarakan urusan pemerintahan. Oleh karena itu, Pemerintah Desa mempunyai tugas dalam 
penyelenggaraan Pemerintahan desa, pelaksanaan pembangunan Desa, pembinaaan kemasyarakatan Desa, dan pemberdayaan masyarakat Desa.

Di Indonesia, pendekatan pemberdayaan telah menjadi instrument penting dalam perencanaan pembangunan maupun upaya penanggulangan kemiskinan. Pembangunan yang inklusif saat ini menjadi agenda utama dan pertimbangan penting dalam pembangunan nasional. Kemiskinan menjadi salah satu permasalahan utama dalam pembangunan nasional. Tetapi, kemiskinan bukanlah label utama dari ketidakberdayaan seseorang/kelompok masyarakat. Ras, etnik, jenis kelamin, agama, tempat tinggal (isolasi geografis), status disable, usia, status HIV AIDS, orientasi seksual atau penanda stigma lainnya, bisa menyebabkan seseorang atau sekelompok masyarakat terkucilkan (tereksklusi) dari berbagai proses dan peluang. Eksklusi tersebut bisa terjadi pada tataran sosial, politik maupun ekonomi. Ketidaksetaraan pembangunan jelas menjadi efek dari model pembangunan eksklusif. Aset terbesar akan selalu hanya dimiliki oleh sebagian kecil orang. Hingga saat ini, masih dengan mudah kita temui penerapan prinsip partisipatif dalam proses penyusunan rencana pembangunan desa misalnya, masih dilakukan hanya dengan keterlibatan tokoh-tokoh kunci atau wakil kelompok masyarakat yang biasanya menonjol dalam komunitas dan cenderung kuat posisinya.

Dengan kata lain pembangunan saat ini masih banyak menerapkan model pembangunan eksklusif. Pembangunan yang hanya menjadikan aspek pertumbuhan ekonomi sebagai satu-satunya tujuan pencapaian sehingga terkadang terjadi pertumbuhan ekonomi yang tinggi tanpa pemerataan kesejahteraan. Struktur yang mengakibatkan masyarakat tidak berdaya harus diubah dengan mewujudkan sebuah praktek pembangunan yang berprinsip pada demokrasi, pertumbuhan ekonomi yang menjamin kepentingan rakyat banyak (Appropriate economic growth), kesetaraan gender (gender equlity) dan keadilan antar generasi (intergeneration equity). Untuk menerapkan prinsipprinsip tersebut, dibutuhkan keterlibatan penuh dan aktif semua kelompok kepentingan di masyarakat dalam setiap proses pembangunan. Pada intinya, partisipasi masyarakat haruslah dapat menjawab pertanyaan dari seberapa pentingnya suatu program dilakukan di suatu daerah dan untuk itu tentunya syarat utama yang dibutuhkan adalah keterwakilan kelompok kepentingan dalam masyarakat sebagai pelaku dan penerima manfaat pembangunan.

Banyak isu-isu tentang eksklusi sosial lainnya yang kemudian mencuat ketika negara Indonesia menjadi semakin dewasa dan demokratis, antara lain, isu-isu seperti ketimpangan antar jender, antar etnik, antar agama, antar partai, dan bahkan antar alumni perguruan tinggi, dalam memperoleh sumberdaya dan peluang berpartisipasi di bidang ekonomi, politik dan pasar kerja. Isuisu seperti ini tentu merupakan bahan kajian penting tentang eksklusi sosial yang dapat menjelaskan mengapa banyak sekali permasalah sosial, terutama kemiskinan dan deprivasi, yang tidak terselesaikan hingga saat ini.

Kelompok terpinggirkan, yang lemah dan rentan baik secara posisi, keadaan fisik maupun stigma sosial justru jarang terwakili dan karenanya tidak memiliki akses pada perencanaan dan pengambilan keputusan maupun manfaat dari keputusan yang diambil. Akibatnya, berbagai kepentingan kelompok ini tidak terwakili dan berdampak pada produk-produk pembangunan seperti layanan dan fasilitas publik yang tidak bisa diakses, tidak dimanfaatkan atau malah tidak dapat digunakan baik oleh kelompok terpinggirkan maupun oleh masyarakat umum. Padahal, dengan mendorong partisipasi dari seluruh kelompok yang ada dalam masyarakat, sebetulnya kita telah mulai melakukan suatu penguatan agar masyarakat memiliki kemampuan untuk dapat menyuarakan sendiri kebutuhan dan menganalisa kemampuan dan prasyarat apa yang paling mereka butuhkan agar lahir sebuah program yang memang betul-betul bermanfaat bagi semua orang.

Pembangunan masyarakat berarti menaruh kepercayaan pada kemampuan yang ada dalam diri masyarakat itu sendiri. Kepercayaan ini dinyatakan dalam bentuk kesempatan yang sama, kebebasan memilih dan kekuasaan untuk memilih (empowerment). 


\section{Metode}

Tulisan ini merupakan kajian literatur yang mengkaji konsep dan pentingnya inklusi sosial dalam ranah pemerintahan terkecil yaitu desa. Tulisan ini memberikan pemantapan dan penegasan tentang pentingnya inklusi sosial dalam ranah desa. Melalui literatur dan penelitian yang ada, tulisan ini mencoba untuk menganalisis penyandang disabilitas tidak hanya sebagai objek namun juga subjek pembangunan yang memiliki hak dilibatkan dalam proses pembangunan sama seperti masyarakat pada umumnya. Data dan informasi yang diperoleh dianalisis secara deskriptif, tidak hanya menggambarkan namun juga menguraikan serta memberikan penjelasan untuk menguatkan diskursus mengenai desa inklusi.

\section{Hasil dan Pembahasan}

\section{A. Pembangunan Desa; Pembangunan yang Berkeadilan}

Pasca Millenium Development Goals (MDG's) yang dilanjutkan dengan Sustainable Development Goals (SGD's) Pemerintah Indonesia terus berupaya memberikan perhatian terhadap pembangunan yang berkeadilan dan memihak kepada kelompok terpinggirkan. Disadari betul bahwa kelompok ini jumlahnya jutaan bahkan puluhan juta adalah kelompok yang paling tertinggalkan dalam pembangunan. Fokus pembangunan di Indonesia saat ini adalah dengan melibatkan kelompok terpinggirkan baik karena posisi atau kelas ekonomi dan sosial tergolong rendah, letak tempat tinggal atau secara geografis sulit terjangkau, menurunkan tingkat kesenjangan pembangunan antara wilayah barat dan timur, jenis kelamin, etnis minoritas, perbedaan orientasi seksual, kelompok umur, keterbatasan fisik dan lain-lain.

Pembangunan desa, berdasarkan Permendesa Nomor 5 Tahun 2015 tentang Prioritas Penggunaan Dana Desa, dilakukan melalui pemenuhan kebutuhan dasar, pembangunan sarana desa, pembangunan prasarana desa, pengembangan potensi ekonomi lokal, dan pemanfaatan sumberdaya alam dan lingkungan hidup berkelanjutan. Pembangunan desa diharapkan mengedepankan kebersamaan, kekeluargaan, dan kegotongroyongan guna mewujudkan pengarusutamaan perdamaian dan keadilan sosial. Untuk meningkatkan kesejahteraan dan pemerataan pembangunan desa salah satunya adalah melalui penguatan masyarakat desa sebagai subjek pembangunan. Berdasarkan PP Nomor 60 tahun 2014 pasal 19(2) dana desa diprioritaskan untuk membiayai pembangunan dan pemberdayaan masyarakat; diperkuat melalui Permendesa PDTT Nomor 5 Tahun 2015 pasal 2 bahwa dana desa yang bersumber dari APBN digunakan untuk mendanai pelaksanaan kewenangan berdasarkan hak asal usul dan kewenangan lokal skala desa yang diatur dan diurus oleh desa; dan pasal 3 yang memprioritaskan belanja pembangunan dan pemberdayaan masyarakat desa.

Undang-Undang Nomor 6 Tahun 2014 tentang desa, terutama dalam pasal 3 telah menetapkan asas partisipasi, kesetaraan dan pemberdayaan. Ketiga asas sebagai fondasi pembangunan desa yang inklusif, di mana semua orang, termasuk kelompok terpinggirkan memiliki akses dan kontrol yang sama dalam pembangunan desa. Begitu pula dalam tujuan pengaturan desa yang disebutkan pada pasal 4 yang berbunyi "mendorong prakarsa, gerakan, dan partisipasi masyarakat desa untuk pengembangan potensi dan aset desa guna kesejahteraan bersama" serta huruf i "memperkuat masyarakat desa sebagai subyek pembangunan".

Inklusi adalah proses membangun hubungan sosial dan menghormati keberagaman individu serta komunitas, sehingga mereka dapat berpartisipasi penuh dalam pengambilan keputusan, kehidupan ekonomi, sosial, politik, budaya, serta memiliki akses dan kontrol yang sama atas sumber daya (untuk memenuhi kebutuhan dasar) dalam rangka menikmati standar kesejahteraan yang dianggap layak di dalam kelompok masyarakat yang bersangkutan. Sementara eksklusi adalah proses yang menghalangi atau menghambat individu dan komunitas, untuk memiliki akses dan 
kontrol terhadap sumber daya yang dibutuhkan dan berpartisipasi dalam kegiatan ekonomi, sosial, politik dan budaya dalam rangka menikmati standar kesejahteraan yang layak dalam masyarakat.

Tyahta Supriyatna (dalam Yulisnaini, 2018:9) mengemukakan bahwa pemberdayaan merupakan kegiatan yang berusaha untuk membangun kemandirian serta jati diri manusia atas sumberdaya kemanusiaannya yang berupa kemampuan dan kekuatan untuk hidup melalui proses pembinaan dan bantuan teknis maupun bimbingan. Makna pemberdayaan tersebut sejalan dengan konsepsi inklusi sosial yang mengarah adanya kemampuan dan daya bagi masyarakat rawan marginal. Sedangkan partisipasi memiliki keterkaitan dengan inklusi sosial dikarenakan inklusi sosial berusaha menghadirkan kondisi dimana individu atau kelompok tertentu yang rawan tereksklusi mampu berperan dalam lingkungan masyarakatnya dan partisipasi sejalan dengan hal yang demikian karena partisipasi merupakan aktivitas atau kegiatan yang mana terdapat keterlibatan kelompok atau individu dalam upaya mencapai tujuan serta terdapat adanya pembagian kewenangan atau tanggungjawab bersama dalam kegiatan tersebut (Dadan Rohimat, Rita Rahmawati, 2017:75).

Dalam kehidupan bermasyarakat, status eksklusi tersebut melekat sebagai stigma negatif yang menyebabkan seseorang terdiskriminasi untuk mendapatkan layanan dasar dan terkucilkan dalam relasinya dengan masyarakat lainnya. Kelompok masyarakat tersebut hidup di tengah-tengah masyarakat namun mengalami eksklusi dan diskriminasi karena dianggap "berbeda". Berdasarkan studi dari Prof. Hillary Silver dari Bown University, kelompok tereksklusi di atas mendapatkan hambatan dalam:

a. Mendapatkan identitas legal (KTP, akta kelahiran, Jamkesmas dll)

b. Berpartisipasi dalam ekonomi

c. Mengakses layanan kesehatan dasar

d. Mengakses layanan pendidikan dasar

e. Berinteraksi dengan masyarakat dan kesempatan untuk berperan dalam masyarakat.

Eksklusi ini terjadi secara terus-menerus antar generasi sehingga pihak-pihak yang mengeksklusi seringkali tidak menyadari dan menganggap sebagai kewajaran. Silver menegaskan dalam studinya bahwa kelompok-kelompok di atas umumnya adalah kelompok yang paling miskin dalam masyarakat. Miskin secara ekonomi, politik dan sosial.

Oleh karena itu, dalam merumuskan rencana pembangunan, beberapa aspek di bawah ini sangat penting untuk menjadi perhatian:

a. Inklusi dalam Kebijakan.

- Fokus pada upaya menjamin semua warga negara memiliki kapabilitas, kesempatan, dan tanggung jawab dan sumber daya untuk belajar, bekerja dan berhubungan dengan warga yang lain dan memiliki kebebasan untuk berpendapat.

- Belajar dan berpartisipasi dalam pendidikan dan pelatihan.

- Bekerja dan berpartisipasi dalam kerja-kerja berbayar atau kerja-kerja sukarela. Pelibatan sosial dan berhubungan dengan orang lain, akses terhadap layanan publik dan partisipasi dalam kegiatan kemasyarakatan, kebudayaan dan rekreatif.

- Memiliki suara dalam pengambilan keputusan yang memengaruhi mereka.

b. Inklusi dalam Program.

Memberikan dukungan dan bantuan agar orang dengan akses terbatas dalam belajar, bekerja, terlibat dalam kegiatan sosial, dan menyuarakan kepentingan dan kebutuhan mereka, dan terlibat dalam proses pengambilan keputusan

c. Inklusi dalam Layanan.

Memberikan layanan yang ramah terhadap orang dengan kemampuan, ketersediaan, keterjangkauan terbatas. Memberikan kualitas layanan terbaik dengan standard tertinggi, aksesibilitas, partisipasi, mekanisme pengaduan dan penanganan keluhan. 
Dalam pembangunan desa dapat dimaknai bahwa inklusi sosial sebagai nilai memperjuangkan masyarakat yang rawan marginalisasi untuk mencapai kondisi idealnya dan menjadi subjek pembangunan dalam pembangunan desa.

\section{B. Pengarusutamaan Gender dan Inklusi Sosial dalam Pembangunan Desa}

Setiap kelompok dalam sebuah masyarakat kerap kali memiliki perbedaan dalam prioritas, hambatan dan pilihan terkait dengan pembangunan. Berbeda kelompok berbeda pula bagaimana mereka mempengaruhi dan dipengaruhi oleh program-program pembangunan. Untuk meningkatkan efektivitas, pertimbangan-pertimbangan tersebut perlu disikapi dalam semua perencanaan dan penanganan program agar dapat menghasilkan efisiensi dan keberlanjutan serta memperbaiki kondisi ketidaksetaraan yang ada.

Pengertian kata gender sama sekali berbeda dengan pengertian kata jenis kelamin. Gender bukanlah perempuan ataupun laki-laki. Gender hanya memuat fungsi dan peran sosial laki-laki dan perempuan yang terbentuk oleh lingkungan tempat kita berada. Gender diciptakan melalui proses sosial budaya yang panjang dalam lingkup suatu masyarakat tertentu sehingga dapat berbeda dari satu tempat ke tempat lainnya. Gender juga berubah dari waktu ke waktu sehingga bisa berlainan dari satu generasi ke generasi berikutnya. Di masa lalu perempuan yang memakai celana panjang dianggap tidak pantas sedangkan saat ini dianggap hal yang baik untuk perempuan aktif (Williamde Vries, 2006). Berbeda dengan jenis kelamin, gender merupakan konsep yang dipergunakan untuk menggambarkan peran dan relasi sosial laki-laki dan perempuan dan sekaligus sebagai sebuah rumusan peran yang melekat pada laki-laki dan perempuan di dalam sebuah masyarakat.

Bicara gender, berarti juga kita bicara tentang stereotip dan ideal, yang berkaitan dengan konsep peran. Stereotip memberikan arah pada perilaku seseorang karena seringkali menentukan cara orang memandang suatu kelompok atau cara seseorang berinteraksi dengan orang lain. Karena masyarakat biasanya kurang bisa menerima perilaku yang menyimpang dari norma standar, berkembanglah mitos bahwa ada dua gender yang sangat berbeda satu dengan yang lainnya. Anggapan yang belakangan ini diperdebatkan karena pengetahuan baru bahwa ada perempuan atau lelaki yang menampilkan karakteristik perilaku, dan sikap yang tidak sesuai dengan harapan sosial tentang ciri khas perempuan atau lelaki (Sadeli, 2010).

Oleh karena dianggap menyimpang, tidak sesuai dengan nilai, norma dan harapan masyarakat maka diberikanlah kepadanya "sanksi sosial" berupa pelabelan (stereotip), peminggiran (marginalisasi), tidak diperhitungkan/dipertimbangkan keberadaannya/pengabaian (subordinasi), kekerasan baik secara fisik, verbal, psikologis maupun sumber terhadap akses ekonomi serta beban ganda, kelimanya sering kali lebih banyak dialami perempuan karena di dalam masyarakat seorang perempuan diharapkan bertindak, bersikap, berperilaku, bertutur, sesuai dengan standar yang ada daalam masyarakat.

Terminologi "kesetaraan gender" seringkali disalahartikan dengan mengambil alih pekerjaan dan tanggungjawab laki-laki. Kesetaraan gender bukan berarti memindahkan pekerjaan laki-laki ke pundak perempuan, bukan pula mengambil alih tugas dan kewajiban suami oleh istrinya. Jika hal ini terjadi, bukan 'kesetaraan' yang tercipta, melainkan penambahan beban dan penderitaan kepada perempuan.

Inti dari kesetaraan dan keadilan gender adalah bagaimana masyarakat berpikir dan bertindak serta memandang semua orang pada kedudukan yang sama dan sejajar. Bagaimana lakilaki dan perempuan dilihat sebagai manusia yang utuh, yang sama dan senilai dalam proses hidup dan menikmati kehidupan. Bagaimana perempuan dan laki-laki berada pada posisi yang setara dalam proses pengambilan keputusan, mendapatkan peluang dan kesempatan dan memperoleh manfaat yang sama dalam mengisi pembangunan. Kesetaraan gender memberikan penghargaan dan 
kesempatan yang sama pada perempuan dan laki-laki dalam menentukan keinginannya dan menggunakan kemampuannya secara maksimal di berbagai bidang. (Willian-de Vries, 2006).

Sedangkan perencanaan pembangunan yang inklusif mensyaratkan keterlibatan, pengenalan hak dan identifikasi kebutuhan khusus kelompok terpinggirkan dalam tiap tahapan dan unsur-unsurnya. Oleh karena itu, perencanaan pembangunan yang direncanakan adalah perencanaan yang terpadu, dengan memperhatikan, mempertimbangkan dan berpihak pada kelompok terpinggirkan. Wujud dari perhatian, pertimbangan dan keberpihakan ini bisa terlihat baik pada proses penilaian, perencanaan, pelaksanaan dan monitoring serta evaluasi dengan melibatkan kelompok terpinggirkan maupun wujudnya dalam usulan program yang disetujui dalam RPJMD/RPJM Desa/RKP Desa serta wujudnya dalam anggaran dan pelaksanaannya. Perlu keterlibatan dan kontribusi semua pihak agar ruang partisipasi, kesetraaan peluang dan manfaat pembangunan dapat diakses, dinikmati dan dikontrol oleh semua warga masyarakat.

Perencanaan pembangunan yang memperhatikan, memasukkan pengalaman aspirasi, kebutuhan potensi dan penyelesaian permasalahan perempuan dan laki-laki dalam proses penyusunan kebijakan dan program pembangunan desa dikenal sebagai Perencanaan Responsif Gender (PRG). Istilah lain terkait ini adalah Anggaran Responsif Gender (ARG), yakni anggaran yang responsif terhadap kebutuhan perempuan dan laki-laki dan memerikan dampak/manfaat yang setara bagi perempun dan laki-laki. Syarat utama untuk melaksanakan PRG dan ARG adalah kemauan politik dan komitmen dari pembuat kebijakan publik (Dalam hal ini kepala pemerintahan termasuk kepala desa).

Terdapat beberapa penelitian terdahulu yang mengaitkan inklusi sosial dengan pembangunan desa. Pada penelitian yang dilakukan Dekki Umamur Ra'is (2017) dengan karya ilmiahnya yang berjudul "Peta Inklusi Sosial dalam Regulasi Desa" menghasilkan kesimpulan bahwa inklusi sosial adalah salah satu tujuan yang dibawa dalam Undang-Undang Desa, yang memiliki arah untuk membuat kemiskinan berakhir, mendorong kebersamaan masyarakat dalam kemakmuran dan menstimulasi keterlibatan segenap warga desa dalam kehidupan masyarakat. Kemudian ada penelitian berjudul"Perspektif Inklusi Sosial dalam UU Nomor 6 Tahun 2014 tentang Desa: Kebijakan dan Tantangan Implementas", karya dari Rikardo Simarmata dan R. Yando Zakaria (2017) yang menyatakan bahwa masih terdapat kelemahan pada Undang-Undang Desa dalam membawa inklusi sosial dan perlu menjadikan inklusi sosial sebagai perspektif yang berlaku menyeluruh, menegaskan cakupan yang menjadi kelompok marginal dan menegaskan serta meluaskan jaminan-jaminan yang ditujukan untuk kelompok marginal. Hal ini menunjukkan betapa pentingnya inklusi soial dalam pembangunan desa guna menghapus eksklusi pada masyarakat sehingga tujuan dari pembangunan desa yang dicita-citakan dalam Undang-Undang Desa dapat tercapai bagi seluruh lapisan masyarakat desa.

Pembahasan mengenai inklusivitas dan gender dalam kaitannya dengan pembangunan, harus terlebih dahulu memastikan keberadaan komponen yang ada dalam masyarakat dengan melakukan identifikasi berbagai kelompok kepentingan yang ada dalam masyarakat. Setiap satuan masyarakat pastilah terdiri dari berbagai kelompok kepentingan seperti profesi, status soaial, kelompok umur, tingkat kesejahteraan, kemampuan (ability), keterampilan dan lain sebagainya. Identifikasi terhadap keberadaan berbagai kelompok kepentingan ini harus dilanjutkan dengan identifikasi masalah, kebutuhan, sumber daya (internal dan eksternal yang dapat mengatasi masalah dan kebutuhan) serta program atau kegiatan yang ditawarkan. Dalam hal identifikasi, terutama dalam hal masalah dan sumber daya, harus dipastikan berbagai aspek seperti fisik, alam, manusia, sosial dan finansial dikaji secara proporsional. Ini berguna untuk mendorong partisipasi dan kemandirian masyarakat dalam mengisi pembangunan.

Selain itu juga harus diperhatikan kesenjangan dari aspek akses, yaitu mengukur seberapa besar peluang dan kesempatan, terutama kelompok terpinggirkan untuk memanfaatkan sumber daya 
baik alam, sosial, politik maupun waktu; partsipasi yakni keterlibatan atau keterwakilan kelompok terpinggirkan dalam program, kegiatan, pengambilan keputusan dalam pembangunan untuk melihat besaran proporsi kelompok dalam masyarakat yang terpinggirkan; Kontrol yakni kekuasaan untuk memutuskan bagaimana menggunakan sumber daya dan siapa yang memiliki akses terhadap penggunaan sumber daya tersebut; serta manfaat berkaitan dengan hasil-hasil dari suatu proses pembangunan untuk melihat proporsi manfaat pembangunan yang diterima kelompok terpinggirkan, apakah manfaat tersebut cenderung menguntungkan salah satu kelompok dalam masyarakat.

Pendekatan eksklusi sosial yang lebih menekankan upaya mengatasi ketidaksetaraan hubungan antara kelompok dominan yang menguasai berbagai sumberdaya dengan kelompokkelompok lainnya yang mengalami deprivasi dan kemiskinan karena tereksklusi dapat mengatasi kekurangan dari pendekatan modal sosial yang digunakan sebagai kerangka acuan dalam berbagai upaya pembangunan untuk meningkatkan kesejahteraan masyarakat.

\section{Kesimpulan}

Pendekatan inklusi sosial mendorong agar seluruh elemen masyarakat mendapat perlakuan yang setara dan memperoleh kesempatan yang sama sebagai warga negara, terlepas dari perbedaan apapun. Inklusi sosial merangkul semua warga negara Indonesia yang mengalami stigma dan marginalisasi, dengan mengajak masyarakat luas untuk bertindak inklusif dalam kehidupan seharihari secara suka rela tanpa memaksa. Inklusi sosial dalam pembangunan desa merupakan nilai yang mengarahkan masyarakat kepada dua bentuk pergerakan, yaitu pergerakan masyarakat sebagai subjek pembangunan secara regulatif berdasar undang-undang dan pergerakan masyarakat sebagai subjek yang mengikis marginalisasinya. Inklusi sosial memerlukan pemahaman bahwa "yang di dalam" perlu berhenti mengucilkan dan mulai menerima "pendatang". Membuka pintu berarti mengundang "orang yang tereksklusi" untuk membangun relasi baru dan menyadari hak-hak formalnya. Proses ini mungkin mengganggu di awal, namun berkontribusi pada stabilitas sosial, kohesi dan solidaritas dalam jangka panjang.

\section{Daftar Pustaka}

Dadan Rohimat, Rita Rahmawati, G. G. S. 2017. Partisipasi Masyarakat Dalam Implementasi

Program Kotaku / Pnpm Di Kecamatan Ciawi, 3, 71-80.

Handicap International, Care, Plan International, Uni Eropa, 2013, Memadukan Pengurangan Risiko Bencana Inklusif dalam Perencanaan Pembangunan.

Kartasasmita, Ginanjar, 1997, Pemberdayaan Masyarakat: Konsep Pembangunan Yang Berakar Pada Masyarakat, Surabaya.

Sadeli, Saparinah, 2010, Berbeda Tapi Setara; Pemikiran tentang Kajian Perempuan, PT. Kompas Media Nusantara, Jakarta.

Simarmata, R. 2017. Perspektif Inklusi Sosial Dalam Uu Nomor 6 Tahun 2014 Tentang Desa : Kebijakan Dan Tantangan Implementasi. Transformasi Sosial, 7-27.

Sumaryadi, I. Nyoman, 2005, Perencanaan Pembangunan Daerah Otonom dan Pemberdayaan Masyarakat, penerbit Citra Utama, Jakarta. 
William-de Vries, 2006, Gender bukan Tabu: Catatan perjalanan Fasilitasi Kelompok Perempuan di Jambi, Center for International Forestry (CIFOR)- Bogor.

Yulisnaini, E. 2019. Peran Komunitas Young Voices Dalam Pemberdayaan Disabilitas Di Kota Banda Aceh.

\section{Peraturan Perundang-undangan}

Instruksi Presiden (Inpres) Nomor 9 Tahun 2000 tentang Pengarusutamaan Gender dalam Pembangunan Nasional.

Permendagri No. 78 Tahun 2015 tentang Rencana Kerja Kementerian Dalam Negeri Tahun 2016.

Undang-undang No 6 Tahun 2014 tentang Desa. 